\title{
INFLUENCE OF METHYL AND ISOPROPYL $N$-METHYL ANTRANILATES ON CARBON TETRACHLORIDE-INDUCED CHANGES IN RAT LIVER MORPHOLOGY AND FUNCTION ${ }^{\dagger}$
}

\author{
UDC 547.583.5 : 615.244
}

\author{
Niko S. Radulović ${ }^{1 *}$, Pavle J. Randjelović ${ }^{2}$, Nikola M. Stojanović ${ }^{3}$, \\ Ivan R. Ilić ${ }^{4}$, Ana B. Miltojević ${ }^{1}$ \\ ${ }^{1}$ Department of Chemistry, Faculty of Science and Mathematics, University of Niš, \\ Višegradska 33, 18000 Niš, Serbia \\ ${ }^{2}$ Department of Physiology, Faculty of Medicine, University of Niš, \\ Zorana Đinđića 81, 18000 Niš, Serbia \\ ${ }^{3}$ Faculty of Medicine, University of Niš, Zorana Đinđića 81, 18000 Niš, Serbia \\ ${ }^{4}$ Institute of Pathology, Faculty of Medicine, University of Niš, \\ Zorana Đinđića 81, 18000 Niš, Serbia
}

\begin{abstract}
The aim of the present study was to examine potential protective effects of methyl N-methylanthranilate $(M)$ and isopropyl $\mathrm{N}$-methylanthranilate $(I)$ in a rat model of acute intoxication with carbon tetrachloride $\left(\mathrm{CCl}_{4}\right)$ by tracking the changes in liver morphology and function. Serum transaminase and bilirubin were significantly elevated in animals treated with $\mathrm{CCl}_{4}$ alone. A pretreatment with $\mathrm{M}$ and I prior to the administration of $\mathrm{CCl}_{4}$ significantly prevented the increase of serum levels of liver damage markers. Histopathological evaluation of the livers of the test animals also revealed that $M$ and I reduced the incidence of liver lesions. Our experiments showed that both $\mathrm{M}$ and I possess protective effect in $\mathrm{CCl}_{4}$-induced liver damage in rats. The results are of interest due to the presence of natural or synthetic $M$ in the human diet.
\end{abstract}

Key words: carbon tetrachloride, methyl and isopropyl N-methyl anthranilates, liver, transaminases

\section{INTRODUCTION}

Methyl anthranilate and methyl $N$-methylanthranilate (M) are flavoring esters added to many food products such as ice cream, candy and chewing gum [1]. The first ester is also

Received July $07^{\text {th }}, 2013$; revised September $03^{\text {rd }}, 2013$; accepted October $13^{\text {th }}, 2013$.

${ }^{\dagger}$ This work was funded by the Ministry of Education, Science and Technological Development of Serbia (Project 172061).

* Corresponding author. Tel.: +381 18533 015; fax: +381 18533 014. E-mail address: nikoradulovic@yahoo.com (N.S. Radulović). 
very important in perfume industry and is additionally used as a flavoring for nonalcoholic beverages (methyl anthranilate is one of the four important odorants identified in Pinot noir wines as well) [2]. Recently published results show that $\mathrm{M}$ and isopropyl $\mathrm{N}$ methylanthranilate (I), both occurring naturally in medicinal and edible plants, produce a dose-responsive antinociceptive activity in chemical and thermal models of nociception in mice [3]. Also, anxiolytic, antidepressant and diazepam-induced sleep modulating activities were observed in animals that received $M$ and I [4], suggesting a polypharmacological versatility of these compounds.

Carbon tetrachloride $\left(\mathrm{CCl}_{4}\right)$ is a synthetic industrial chemical used as a solvent that can cause hepatotoxicity and nephrotoxicity in workers exposed to it, as well as in experimental animals [5]. Inhalation, ingestion, skin absorption or intraperitoneal administration to experimental animals causes necrotic damage to cells and tissue, resulting in leakage of their enzymes into the blood stream [6]. Apart from liver, $\mathrm{CCl}_{4}$ can cause disorders in kidneys, lungs, testes and brain, as well as in blood, generating free radicals [7,8]. Trichloromethyl free radicals $\left(\cdot \mathrm{CCl}_{3}\right)$ are generated from $\mathrm{CCl}_{4}$ via a biotransformation by hepatic microsomal Cytochrome P450 [9]. Furthermore, these radicals can form covalent bonds with macromolecules and oxidize them to form lipid, protein, or nucleic acid adducts [10], and to initiate and propagate lipid peroxidation in biological membranes [11].

The aim of the present study was to examine the potential protective effects of $\mathrm{M}$ and $\mathrm{I}$ in a rat model of acute intoxication with $\mathrm{CCl}_{4}$ by tracking changes in liver tissues morphology and function.

\section{MATERIALS AND METHODS}

\subsection{Chemicals and reagents}

Methyl and isopropyl $\mathrm{N}$-methylanthranilates (M and I, respectively) were synthesized following a previously reported procedure [3]. The anesthetic used, ketamine (Ketamidor $10 \%$ ), was obtained from Richter Pharma AG, Wels, Austria.

\subsection{Animals}

Adult male and female Wistar rats weighing 200-250 g were maintained under standard laboratory conditions $-22 \pm 2{ }^{\circ} \mathrm{C}, 60 \%$ humidity and 12/12 (light/dark) cycle, with food and water available ad libitum. All experimental procedures were conducted in accord with the principles of care and use of laboratory animals in research and approved by the local Ethics committee. The approval of the committee (number 01-7289-11) was given on $14^{\text {th }}$ October, 2011. All efforts were made to minimize animal suffering and reduce the number of animals used.

\subsection{Experimental design}

Animals were randomly divided into four experimental groups of six animals each and were kept individually during the entire experiment. Groups one and two were treated daily with $\mathrm{M}$ and I (in a dose of $200 \mathrm{mg} / \mathrm{kg}$ ) for seven days and on the seventh day, $2 \mathrm{~h}$ after the application of the last dose of $\mathrm{M}$ or $\mathrm{I}$, they received $\mathrm{CCl}_{4}$ dissolved in olive oil 
(1:1), at a dose of $1 \mathrm{ml} / \mathrm{kg}$. The control group received olive oil (at $1 \mathrm{ml} / \mathrm{kg}$ ) for seven days. In animals of the remaining group $\left(\mathrm{CCl}_{4}\right.$ group) acute organ damage was produced by the administration of $\mathrm{CCl}_{4}(1 \mathrm{ml} / \mathrm{kg})$ dissolved in olive oil $(1: 1, \mathrm{v} / \mathrm{v})$. All substances were administrated daily by an intraperitoneal injection (i.p.). Twenty-four hours after a $\mathrm{CCl}_{4}$ injection, rats were sacrificed by an overdose of ketamine. The animals and their livers were weighted and corresponding tissue samples were collected for histological analyses. Blood samples, withdrawn by a cardiac puncture, were used for the evaluation of biochemical parameters and were kept at $-80{ }^{\circ} \mathrm{C}$ until use.

\subsection{Biochemical measurements}

The blood was centrifuged at $1500 \mathrm{rpm}$ at $4{ }^{\circ} \mathrm{C}$ for 15 minutes to obtain the serum in which aspartate transaminase (AST), alanine transaminase (ALT), cholesterol (Cho), total (TB) and direct bilirubin (DB) were assayed by Olympus AU680 Chemistry-Immuno Analyzer.

\subsection{Histopathological observation}

The liver tissue specimens separated for histopathological examination were fixed in buffered formaldehyde solution $(10 \%, \mathrm{w} / \mathrm{v})$. The fixed tissues were then dehydrated with ethanol solutions of differing concentration $(50-100 \%, \mathrm{v} / \mathrm{v})$, embedded in paraffin, cut into 4-5 $\mu \mathrm{m}$ thick sections, stained with hematoxylin and eosin (HE) and periodic acidSchiff (PAS) and further examined with an Olympus BH2 light microscope. The extent of $\mathrm{CCl}_{4}$-induced liver damage was evaluated based on morphological changes in sections stained with HE. A score system was used for the histopathological examinations. The meaning of grades for liver (mononuclear cell infiltration, vacuolar degeneration, congestion and necrosis) is as follows: absent $(-)$, mild $(+)$, moderate $(++)$ and severe $(+++)$.

\subsection{Statistical analysis}

Results were expressed as the mean \pm SD. Statistically significant differences were determined by one-way analysis of variance (ANOVA) followed by Tukey's post hoc test for multiple comparison (Graph pad Prism version 5.03, San Diego, CA, USA). Probability values (p) less than 0.05 were considered to be statistically significant.

\section{RESULTS AND DISCUSSION}

Serum levels of ALT, AST, TB and DB in animals treated with the substance M and $\mathrm{CCl}_{4}$ were significantly elevated when compared to the control group (vehicle), whereas the same parameters were significantly reduced when compared to the $\mathrm{CCl}_{4}$ group. Such elevations are indicative of liver injury, especially the rise of ALT level [12]. Pretreatment of animals with the substance I did not have any effect on $\mathrm{CCl}_{4}$-induced increase of AST and ALT levels. Serum levels of TB and DB in animals from the group I $+\mathrm{CCl}_{4}$ were significantly elevated when compared to the control group but significantly lower in comparison with the animals treated with $\mathrm{CCl}_{4}$ alone. An effective control of DB and TB levels points towards an early improvement in the secretory mechanism of hepatic cells. 
In addition, no significant difference was found in serum cholesterol levels between the experimental groups (Table 1).

Table 1 Serum biochemical parameters and statistical comparison of the groups of animals after different experimental treatments

\begin{tabular}{|c|c|c|c|c|c|}
\hline Groups & $\begin{array}{l}\text { AST } \\
(\mathrm{U} / \mathrm{L})\end{array}$ & $\begin{array}{l}\text { ALT } \\
(\mathrm{U} / \mathrm{L})\end{array}$ & $\begin{array}{c}\text { Cho } \\
(\mathrm{mmol} / \mathrm{L})\end{array}$ & $\begin{array}{c}\mathrm{TB} \\
(\mu \mathrm{mol} / \mathrm{L})\end{array}$ & $\begin{array}{c}\mathrm{DB} \\
(\mu \mathrm{mol} / \mathrm{L}\end{array}$ \\
\hline Control & $176 \pm 32$ & $37 \pm 2$ & $1.5 \pm 0.3$ & $2.1 \pm 0.1$ & $0.4 \pm 0.1$ \\
\hline $\mathrm{CCl}_{4}$ & $3070 \pm 513$ & $1306 \pm 147^{*}$ & $1.9 \pm 0.2$ & $11 \pm 3^{*}$ & $8.9 \pm 1.8^{*}$ \\
\hline $\mathrm{M}+\mathrm{CCl}_{4}$ & $528 \pm 55^{\dagger \#}$ & $321 \pm 22^{* * \#}$ & $1.6 \pm 0.4$ & $5.7 \pm 0.7^{* \#}$ & $2.4 \pm 0.9^{\ddagger}$ \\
\hline $\mathrm{I}+\mathrm{CCl}_{4}$ & $2985 \pm 124$ & $1119 \pm 373^{*}$ & $1.6 \pm 0.3$ & $7.6 \pm 0.9^{* \#}$ & $4 \pm 1^{\dagger \#}$ \\
\hline
\end{tabular}

The trichloromethyl radical binds to tissue macromolecules, induces peroxidative degradation of membrane lipids and disturbs $\mathrm{Ca}^{2+}$ homeostasis which leads to tissue injury and/or depletion of antioxidant defenses. Thus, the antioxidant activity or the inhibition of free radicals generation could be an important asset of the anthranilates in the protection against $\mathrm{CCl}_{4}$-induced tissue damage [13]. Another possibility is that the reversal of increased serum enzyme levels in $\mathrm{CCl}_{4}$-induced liver damage by these substances may be due to the prevention of leakage of intracellular enzymes by their membrane stabilizing activity. This is in agreement with the commonly accepted view that serum levels of transaminases return to normal with the healing of hepatic parenchyma and the regeneration of hepatocytes [14]. The efficacy of any hepatoprotective drug is essentially dependent on its capability to either reduce the harmful effects or maintain the normal hepatic physiological mechanisms altered by a hepatotoxin [15].

Body and liver weight changes of rats in each experimental group noted during the treatments are shown in Table 2 . A decrease in body weights was observed in rats that were treated with substances $\mathrm{M}$ and $\mathrm{I}$ in combination with $\mathrm{CCl}_{4}$ compared to both the positive and negative control groups (Table 2). A significant increase of both absolute and relative liver weight $(\mathrm{p}<0.05)$ was observed for the $\mathrm{CCl}_{4}$-treated rats in comparison to the control group, whereas significant decreases in absolute liver weight were found in animals from the groups treated with a combination of $\mathrm{M}$ or I and $\mathrm{CCl}_{4}$ (Table 2).

The application of $\mathrm{CCl}_{4}$ resulted in a significant increase in relative and absolute liver weights when compared to the control group. Increase in liver weight could be due to an increased blood content, to the dilatation of central veins and sinusoids, swelling of hepatocytes, due to increase in water transport in cells and fatty liver or due to the increase in accumulation of fat in hepatocytes [16]. All these changes were obvious on histopathological examination of our tissue sections. Relative liver weights of animals from groups that received the combination of the anthranilates with $\mathrm{CCl}_{4}$ were similar to the weights of animal livers from the control group. This result may be the consequence of both a decrease in total body weight as well as the protective effect of substances on $\mathrm{CCl}_{4}$-caused damage. 
Table 2 Body and liver weight of rats after different experimental treatments

\begin{tabular}{lccccc}
\hline Groups & $\begin{array}{c}\text { Initial body } \\
\text { weight }(\mathrm{g})\end{array}$ & $\begin{array}{c}\text { Final body } \\
\text { weight }(\mathrm{g})\end{array}$ & $\begin{array}{c}\text { Percent change } \\
\text { in body } \\
\text { weight }(\%)\end{array}$ & $\begin{array}{c}\text { Absolute } \\
\text { liver } \\
\text { weight }(\mathrm{g})\end{array}$ & $\begin{array}{c}\text { Relative liver } \\
\text { weight } \\
\text { (\% to body weight })\end{array}$ \\
\hline Control & $238 \pm 24$ & $267 \pm 30$ & $12 \pm 4$ & $9.2 \pm 0.3$ & $3.4 \pm 0.3$ \\
$\mathrm{CCl}_{4}$ & $253 \pm 28$ & $258 \pm 29$ & $3.4 \pm 0.1^{*}$ & $11.2 \pm 0.3^{\dagger}$ & $4.3 \pm 0.5^{*}$ \\
$\mathrm{M}^{*} \mathrm{CCl}_{4}$ & $226 \pm 22$ & $172 \pm 15^{\dagger \#}$ & $-25 \pm 4^{\dagger \#}$ & $6.8 \pm 0.6^{\dagger \#}$ & $4.0 \pm 0.4$ \\
$\mathrm{I}+\mathrm{CCl}_{4}$ & $243 \pm 26$ & $181 \pm 16^{\dagger \#}$ & $-28 \pm 5^{\dagger \#}$ & $6.1 \pm 0.3^{\dagger \#}$ & $3.8 \pm 0.4$ \\
\hline
\end{tabular}

Values are presented as means \pm SD. $* \mathrm{p}<0.05 ;{ }^{\dagger} \mathrm{p}<0.001$ vs. Control, ${ }^{*} \mathrm{p}<0.001$ vs. $\mathrm{CCl}_{4}$

Histopathological analyses of liver sections of the control and experimental animals are shown in Figure 1. The livers of control rats revealed characteristic hepatic architecture where the central veins, portal tracts, hepatocytes and sinusoids appear normal (Figure 1A). Histological examination of livers of rats that received $\mathrm{CCl}_{4}$ showed massive fatty degeneration and extensive vacuolation with the disappearance of nuclei, gross necrosis, broad infiltration of lymphocytes and Kupffer cells around the central vein as well as the loss of cellular boundaries (Figure 1B). The treatment with $\mathrm{M}$ plus $\mathrm{CCl}_{4}$ resulted in lobules having a normal configuration and a reduction of both degenerative lipid droplets around the centrilobular vein and vacuolated cells when compared to the $\mathrm{CCl}_{4}$ group. However, inflammatory cells were still present (Figure 1C). The improved histology of liver as seen in histopathological observation for animals treated with the substance $\mathrm{M}$ as compared to that seen in animals administered only with $\mathrm{CCl}_{4}$ indicated the possibility that this substance induces an acceleration of regeneration. The treatment with I plus $\mathrm{CCl}_{4}$ also produced necrotic areas in the central lobe area as well as an inflammatory infiltrate; however, the necrotic areas were less extensive than in the livers of rats treated with $\mathrm{CCl}_{4}$ alone, which is in good agreement with the results of the serum AST and ALT levels. Thus, the administration of I limited the damaged areas to the central zone of lobules. The histomorphological changes were graded and summarized in Table 4. Biochemical findings correlated well with the histological examination. There was a broad infiltration of lymphocytes and Kupffer cells around the central vein coupled with the loss of cellular boundaries (Table 3).

Table 3 Degrees of histopathological lesions of liver in rats after different experimental treatments

\begin{tabular}{lccc}
\hline & \multicolumn{3}{c}{ Liver sections } \\
\cline { 2 - 4 } Groups & $\begin{array}{c}\text { Hydropic and vacuolar } \\
\text { degeneration }\end{array}$ & $\begin{array}{c}\text { Mononuclear cell } \\
\text { infiltration }\end{array}$ & Necrosis \\
\hline Control & - & - & - \\
$\mathrm{CCl}_{4}$ & +++ & +++ & +++ \\
$\mathrm{M}+\mathrm{CCl}_{4}$ & + & ++ & + \\
$\mathrm{I}+\mathrm{CCl}_{4}$ & ++ & ++ & ++ \\
\hline
\end{tabular}

Scoring was done as follows: absent $(-)$, mild $(+)$, moderate $(++)$ and severe $(+++)$ 

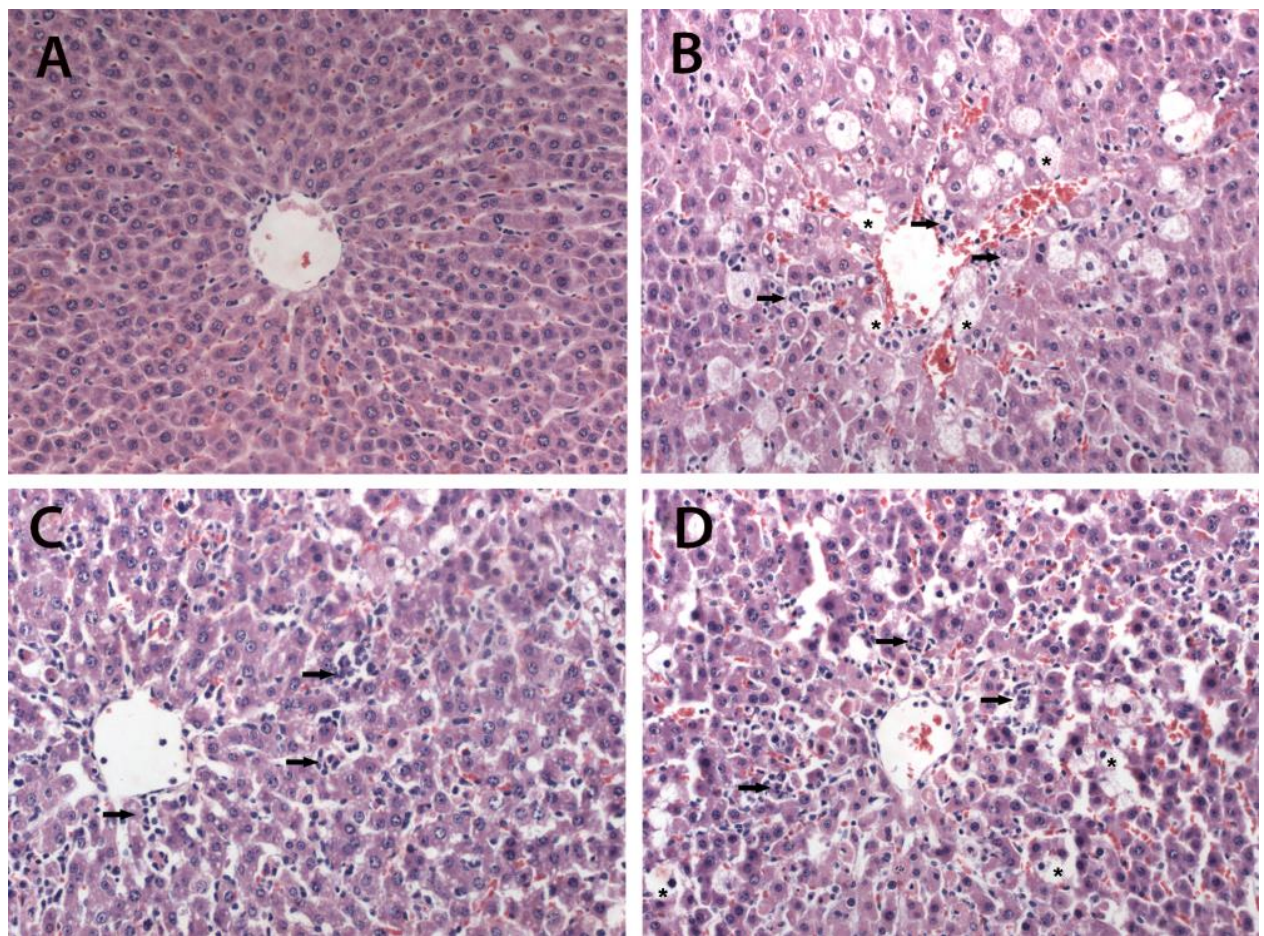

Fig. 1 Histopathological observations of liver sections stained with HE (x 200). (A) control rats (vehicle); (B) $\mathrm{CCl}_{4}$-treated rats; (C) represents a liver section from rats treated with $\mathrm{M}$ plus $\mathrm{CCl}_{4}$ and $(\mathbf{D})$ represents a liver section from rats treated with I plus $\mathrm{CCl}_{4}$ * necrotic cells, $\Rightarrow$ inflammatory cells

Besides their direct damaging effects on tissues, free radicals are able to trigger the accumulation of leukocytes in the tissues involved and thus cause tissue injury indirectly through activated neutrophils. It has been shown that activated neutrophils secrete enzymes (e.g., myeloperoxidase, elastase, and proteases) and liberate oxygen radicals [17]. These findings have been confirmed in our study as mononuclear cell infiltration was observable in liver tissue sections (Figure 1).

\section{CONCLUSION}

Our experiments showed that both methyl and isopropyl $\mathrm{N}$-methylanthranilates possess protective potential in $\mathrm{CCl}_{4}$-induced liver damage in rats. This activity was observed by means of standard biochemical and histopathological analysis. The results are of interest due to the presence of natural or synthetic methyl $N$-methylanthranilate (M) in human diet. 


\section{REFERENCES}

1. Ministry of health and welfare Japan's specification and standards for food additives, $7^{\text {th }}$ edition (in English), Ministry of health and welfare, Japan (2000).

2. L. Moio and P.X. Etievant, Ethyl anthranilate, ethyl cinnamate, ethyl 2,3-dihydrocinnamate and methyl anthranilate: four important contributors to the aroma of Pinot noir wines, American Journal of Enology and Viticulture, 46 (3), 392-398 (1995).

3. N.S. Radulović, A.B. Miltojević, M. McDermott, S. Waldren, J.A. Parnell, M.M. Gomes Pinheiro, P.D. Fernandes and F. de Sousa Menezes, Identification of a new antinociceptive alkaloid isopropyl $N$-methylanthranilate from the essential oil of Choisya ternata Kunth, Journal of Ethnopharmacology, 135 (3), 610-619 (2011).

4. N.S. Radulović, A.B. Miltojević, P.J. Randjelović, N.M. Stojanović and F. Boylan, Effects of methyl and isopropyl $N$-methylanthranilates from Choisya ternata Kunth (Rutaceae) on experimental anxiety and depression in mice, Phytotherapy Research, 27 (9), 1334-1338 (2012).

5. P. Abraham, G. Wilfred, S.P. Cathrine, Oxidative damage to lipids and proteins of the lungs, testis and kidney of rats during $\mathrm{CCl}_{4}$ intoxication, Clinical Acta, $\mathbf{2 8 9}$ (1-2), 177-179 (1999).

6. F.O. Obi, L.A. Omogbai, O.S.J. Oriafo, O.D. Ovat, Effect of a short time post $\mathrm{CCl}_{4}$ treatment interval on rat plasma enzyme levels and percentage mortality, Journal of Applied Sciences \& Environmental Management, 6 (1), 5-8 (2001).

7. F.F. Ahamad, D.L. Cowan and A.Y. Sun, Detection of free radical formation in various tissues after acute carbon tetrachloride administration in gerbil, Life Sciences, 41 (22), 2469-2475 (1987).

8. F. Ozturk, M. Ucar, I.C. Ozturk, N. Vardi and K. Batcioglu, Carbon tetrachloride induced nephrotoxicity and protective effects of betaine in Sprague-dawley rats, Urology, 62 (2), 353-356 (2003).

9. J.A. Brent and B.H. Rumack, Role of free radicals in toxic hepatic injury. II. Are free radicals the cause of toxin-induced liver injury?, Journal of Toxicology - Clinical Toxicology, 31 (1), 173-196 (1993).

10. R.O. Recknagel and E.A. Glende, Carbon tetrachloride hepatotoxicity: an example of lethal cleavage, Critical Reviews in Toxicology, 2 (3), 263-297 (1973).

11. P.Y. Lee, P.B. Mccay and K.R. Hornbrook, Evidence for carbon tetrachloride-induced lipid peroxidation in mouse liver, Biochemical Pharmacology, 31 (3), 405-409 (1982).

12. J.K. Lin and C.J. Wang, Protection of Crocin dyes in the acute hepatic damage induced by Aflatoxin B and dimethylnitrosamine in rats, Carcinogenis, 7 (4), 595-599 (1986).

13. J.A.Castro, G.C. Ferrya, C.R. Castro, H. Sasame, O.M. Fenos and J.R. Gillete, Prevention of carbon tetrachloride induced necrosis by inhibitors of drug metabolism. Further studies on the mechanism of their action, Biochemical Pharmacology, 23 (2), 295-302 (1974).

14. M. Thabrew and P. Joice, A comparative study of the efficacy of Pavetta indica and Osbeckia octanda in the treatment of liver dysfunction, Planta Medica, 53 (3), 239-241 (1987).

15. B.R.H. Raghavendran, A. Sathivel, and T. Devaki, Hepatoprotective nature of seaweed alcoholic extract on Acetaminophen induced oxidative stress, Journal of Health Science, 50 (1), $42-46$ (2003).

16. S.L. Robbin, R.S. Cotran and V. Kumar, Robbins pathologic basis of disease, Philadelphia, Saunders, 1989.

17. P.J. Randjelovic, S.R. Veljkovic, N.I. Stojiljkovic, LJ.V. Velickovic, D.T. Sokolovic, M.I. Stoiljkovic, and I.R. Ilic, Protective effect of selenium on gentamicin-induced oxidative stress and nephrotoxicity in rats, Drug and Chemical Toxicology, 35 (2), 141-148 (2012).

\section{UTICAJ METIL- I IZOPROPIL- $N$-METILANTRANILATA NA UGLJEN-TETRAHLORIDOM IZAZVANE PROMENE U FUNKCIJI I MORFOLOGIJI JETRE PACOVA}

$U$ ovom radu ispitivano je potencijalno protektivno dejstvo metil $\mathrm{N}$-metilantranilata $(M)$ i izopropil $\mathrm{N}$-metilantranilata (I) u modelu akutne intoksikacije pacova sa ugljen-tetrahloridom (CCl $)$ praćenjem promena u morfologiji i funkciji jetre. Kod životinja tretiranih sa samo $\mathrm{CCl}_{4}$ značajno su bile povećane vrednosti transaminaza i bilirubina u serumu. Pretretman sa Mi I značajno je umanjio porast serumskih markera oštećenja jetre. Patohistološka analiza tkiva jetre pokazala je da Mi I smanjuju stepen oštećenja jetre. Ovaj eksperiment je pokazao da i M i I imaju protektivno dejstvo kod oštećenja jetre izazvanog $\mathrm{CCl}_{4}$. Ovi rezultati su značajni zbog prisustva prirodnog ili sintetskog $\mathrm{M}$ u ljudskoj ishrani.

Ključne reči: ugljen-tetrahlorid, metil- i izopropil-N-metilantranilati, jetra, transaminaze 